\title{
Consumo, usos e gratificações da audiência das telenovelas
}

\section{Raquel Marques Carriço Ferreira}

\section{Resumo}

0 presente artigo concentra-se nos resultados parciais da tese de doutorado defendida pela autora sobre o consumo das telenovelas, sobretudo, ao que diz respeito às razões pelas quais os telespectadores procuram se expor a tais conteúdos. A abordagem da "teoria fundamentada em dados" foi empregada na investigação para prover um "MODELO DA AUDIÊNCIA DAS TELENOVELAS" firmemente enraizado na perspectiva de 49 receptores entrevistados. 0 modelo resultante revela três categorias de motivos para a audiência: a) Companhia/Passatempo; b) Gerenciamento do humor; c) Integração social/Aconselhamento. Cada grupo de motivos no modelo se associa a particular estratégia e intensidade de exposição às telenovelas, padrões de interação, entre outros. No entanto, aqui, destacarei a descrição de cada categoria motivacional posta em discussão com a literatura que melhor interpretou os dados surgidos da pesquisa indutiva aplicada.

\section{Palavras-Chave}

Telenovelas. Usos e gratificações. Audiência. Consumo. Teoria fundamentada em Dados.

\section{Raquel Marques Carriço Ferreira}

| raquelcarrico@gmail.com

Doutora em Televisão e Cinema pela Universidade Nova de Lisboa. Professora do Curso de Publicidade e Propaganda da Universidade Federal de Sergipe (UFS).

\section{Estudo sobre a audiência das telenovelas}

A descrição dos Usos e Gratificações buscados nas telenovelas pela sua audiência parte de uma investigação operada em Lisboa, decorrente do intrigante cenário constituído com os conteúdos das telenovelas em Portugal. Em síntese, desde quando a telenovela brasileira Gabriela Cravo e Canela foi transmitida pela RTP1, em 1977, o gênero se tornou extremamente popular no país, sendo então os conteúdos de origem brasileira, um dos de maior impacto em termos de atração da audiência (FERREIRA, 2011).

As telenovelas portuguesas por sua vez passam a ser produzidas e transmitidas timidamente cinco anos mais tarde, quando Vila Faia vai ao ar, em 1982. Com uma produção incipiente e ainda não tão madura quanto as telenovelas de origem brasileira, estas ficavam sempre à margem dos índices de participação conquistados pelas produções brasileiras. 
A ampla distribuição de telenovelas brasileiras nas décadas de 1980 e 1990 em Portugal pode ser associada ao desencadeamento de dois movimentos; o primeiro, da crítica à "invasão brasileira" na televisão portuguesa, e o segundo, do impulsionamento de uma "nova leva" de produções nacionais de telenovelas. Com a pressão da crítica e de órgãos fiscalizadores, somada às condições contextuais produtivas e receptivas dos conteúdos portugueses, a disparidade entre a importação dos conteúdos estrangeiros e a veiculação dos nacionais encontrou seu caminho de superação.

Em geral, as emissoras operantes em Portugal gradativamente passaram a privilegiar obras europeias e principalmente, nacionais portuguesas, sobretudo, em função do regime de operação da televisão em Portugal que segue a orientação tanto das diretrizes da convenção europeia sobre a televisão, quanto do Estado, através da Lei da televisão, que sugere que "[...] as operadoras de televisão devem incorporar uma percentagem majoritária de obras com destaque à produção nacional."1

Adicionalmente, 0 período que antecede os anos da década de 2000 se encontrava marcado por inúmeras iniciativas voltadas ao incremento da produção nacional. No final da década de 1990 já haviam sido criadas duas organizações nesse sentido, a Comissão Interministerial para 0 Audiovisual (1997) e a Plataforma do Audiovisual, com o objetivo de propor linhas de ação e fomento à produção de conteúdos nacionais. 0 Governo português também passa a empreender uma reestruturação no setor público de televisão em que subsidiaria 30\% da empresa autônoma Formas e Conteúdos, para assegurar a produção de conteúdos ficcionais já no ano de 2000 (CUNHA; BURNAY, 2006).

Desse modo, a telenovela de origem nacional não só se expande em número de títulos transmitidos como também passa a se destacar em termos produtivos, o que abala os índices de participação de audiência das telenovelas brasileiras. Assim, a partir de 2001, as telenovelas portuguesas tomam para si a participação de audiência que pertenceu por mais de duas décadas às produções brasileiras:

Nesse cenário fica claro a constatação de que a sucessão de conteúdos tais como as telenovelas se estabelecem em uma dinâmica instável e é influenciada por muitas variáveis como as já postas acima, porém, é sem sombra de dúvidas a demanda pelo conteúdo, a força preponderante sobre o processo das transmissões.

É a audiência da televisão que considera por critérios não conhecidos, quais conteúdos 
Gráfico 1 - Participação de audiência ponderada das telenovelas das emissoras RTP1, SIC e TVI nos anos 1999-2010.

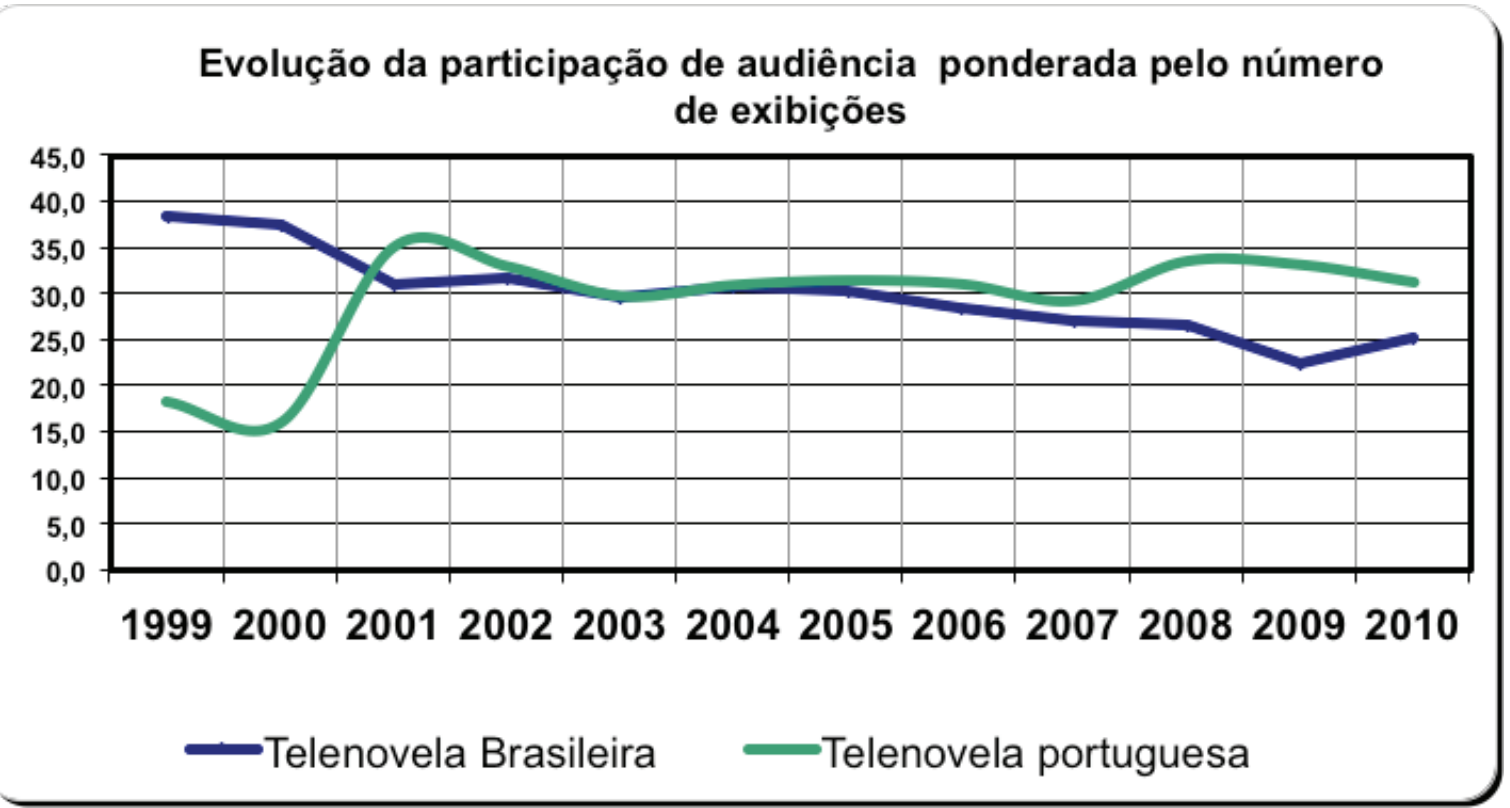

Fonte: FERREIRA, 2011.

"merecem a sua atenção", imputando aos índices, os seus reais interesses. Se as telenovelas

portuguesas detêm hoje predominância na grade de programação em termos de horas de transmissão e índices de participação de audiência, é porque de alguma forma tais conteúdos ofertam prazeres, usos significativos aos seus receptores.

Neste contexto, os conteúdos das telenovelas brasileiras também o fariam, pois, mesmo com menor expressão de sucesso, estes ainda se sustentam na grade de programação da televisão portuguesa com desempenho ainda interessante para as emissoras televisivas, atraindo a participação de cerca de vinte e cinco por cento dos consumidores em seu horário de emissão. Entretanto, falamos exatamente do quê? Por que a audiência se expõe às telenovelas? 0 que move a audiência desses conteúdos?

Assistir às telenovelas tem o mesmo significado e importância para todos os seus telespectadores?

0 que de fato condicionam as escolhas das telenovelas? A audiência é homogeneamente seletiva? Intencionada? Envolvida nos conteúdos das telenovelas?

A investigação e a subsequente formulação dos esclarecimentos sobre os processos de decisão de audiência das telenovelas, os processos de seleção e interação com esses conteúdos bem como os eventos envolvidos na atividade de audiência assim foram investigados. Adiante, descrevo apenas parte dos resultados 
encontrados, nomeadamente, os motivos para a audiência das telenovelas. ${ }^{2}$

\section{Resultados da investigação}

A estruturação da informação colhida permitiu a identificação dos processos básicos aos quais os receptores se envolvem para consolidar a audiência das telenovelas, mas, sobretudo, as razões que motivam o telespectador à audiência:
0 modelo surgido em estudo aponta que as

disposições pessoais do receptor situadas

em contexto e em conjunto com a experiência

gratificante das telenovelas que desencadeiam

"motivos" que energizam novas exposições ao

material relacionado. A princípio, a experiência

gratificante avaliada e identificada se transforma em

um energizador que mobiliza o receptor para a busca

dos conteúdos que demonstram certa probabilidade

de correspondência às expectativas geradas.

Quadro 1 - Estruturação das formulações conceituais a partir dos dados substantivos

\begin{tabular}{|c|c|c|c|}
\hline Código Substantivo & Código Conceitual & $\begin{array}{l}\text { Processo intrínseco } \\
\text { básico }\end{array}$ & Categoria central \\
\hline $\begin{array}{c}\text { Companhia/Passatempo } \\
\text { Escape } \\
\text { Relaxamento } \\
\text { Valorização da autoimagem } \\
\text { Projeção dos sonhos } \\
\text { Fuga do tédio } \\
\text { Aprendizado/ Aconselhamento } \\
\text { Integração social }\end{array}$ & $\begin{array}{c}\text { Ênfase } \\
\text { Hábito } \\
\text { Gerenciamento do humor - } \\
\text { usos da telenovela no contexto } \\
\text { da recepção } \\
\text { Aconselhamento/ } \\
\text { Integração social - usos da } \\
\text { telenovela no contexto pessoal } \\
\text { do receptor }\end{array}$ & $\begin{array}{c}\text { Exposição casual } \\
\text { Percepção de uma } \\
\text { gratificação obtida e avaliação } \\
\text { da experiência da audiência } \\
\text { Eleição, escolha do (s) } \\
\text { conteúdo (s) a ser/serem } \\
\text { consumido (s) } \\
\text { Audiência e avaliação } \\
\text { constante }\end{array}$ & $\begin{array}{c}\text { "Eu estou neste leque } \\
\text { de pessoas que se entregam } \\
\text { aos momentos plásticos } \\
\text { de telenovelas" } \\
\text { Código in vivo }\end{array}$ \\
\hline
\end{tabular}

Fonte: FERREIRA, 2011.

0 método de pesquisa adotado para o empreendimento no estudo proposto foi o da Teoria Fundamentada em Dados (TFD), método qualitativo da investigação social, também conhecida como Grounded Theory apresentada inicialmente por Glaser e Strauss, em 1967. 0s procedimentos da sua prática contemplam muitas práticas inovadoras, e sua adoção partiu fundamentalmente por minha simpatia pela orientação de número sete: a recomendação proposta pela TFD é de que se postergue a revisão da literatura deixando esta fase para ser realizada depois da escrita dos resultados da investigação, permitindo assim ao pesquisador, a possibilidade de abertura e liberdade para a descoberta de novos conceitos, problemas e interpretação dos dados (GLASER, 1998). As teorias conhecidas podem ser um ponto de partida para olhar as informações, mas elas não devem oferecer visões preconizadas que automatizam e até mesmo forçam a análise dos dados. Além do mais, esta posição propõe "empirismo sem paixões", codificação rigorosa e com ênfase na emergência de descobertas. 0 que TFD sugere em seu guia é que se postergue a revisão de literatura exatamente para que o pesquisador não se aproxime do seu trabalho investigativo com "formulações preconcebidas". Assim, somente na análise final dos dados é que busquei a literatura relacionada para incorporá-la aos resultados como conhecimento adicional à estrutura inicialmente desenvolvida em campo. Para obtenção dos dados foram utilizadas entrevistas em profundidade com 49 telespectadores que se autodeclararam consumidores das telenovelas, e que faziam parte de uma amostra intencional estratificada para garantir diversidade interna à amostra. 
Tudo se inicia então com uma experiência casual do material em que o receptor avalia 0 seu devido "valor" e desenvolve (a partir do resultado da avaliação) "certo" relacionamento com o material em questão. Dependendo da afinidade ou do grau de correspondência entre as expectativas e a oferta das gratificações nas telenovelas, o receptor pode estabelecer uma relação comprometida com seus conteúdos, com uma audiência empenhada, determinada e dedicada, variando até mesmo em posição oposta a esta, com um consumo fortuito e eventual.

De fato, o relacionamento do receptor com as telenovelas está sujeito às variações da capacidade de afinidade entre as suas expectativas e seus correspondentes, o que acaba por influenciar determinados modelos de audiência dos conteúdos, de regularidade de exposição, de envolvimento com o material etc.

A decisão de consumo das telenovelas se mostrou cíclico e demandando do receptor constante avaliação da capacidade de fornecimento das recompensas projetadas em seu conteúdo, bem como avaliação da estrutura maior de fornecimento de conteúdos concorrentes às telenovelas que poderiam eventualmente substituí-las.

A exploração detalhada dos códigos conceituais que demarcam as razões pelos quais a audiência se expõe às telenovelas é posta adiante e em discussão com a literatura que se mostrou mais hábil para interpretar os resultados encontrados.

\section{Motivos para audiência das telenovelas}

As motivações para a audiência das telenovelas observadas se mostraram substancialmente influentes no fenômeno em estudo. Estas foram entendidas como as variáveis que sintetizam as perspectivas pessoais para a audiência das telenovelas, circunstanciadas pelos contextos particulares dos receptores.

Em pesquisa, foram encontrados oito diferentes motivos que conduzem 0 consumo das telenovelas e que puderam ser genericamente reduzidas a três. Companhia/ passatempo, Escape, Relaxamento, Valorização da autoimagem, Projeção dos sonhos, Fuga do tédio, Integração social e Aprendizagem/aconselhamento foram os códigos substantivos encontrados, reduzidos aos códigos teóricos rotulados como: 1) Companhia/passatempo; 2) Gerenciamento do humor; 3) Integração social/aconselhamento.

Figura 1 - Motivos para a audiência das telenovelas

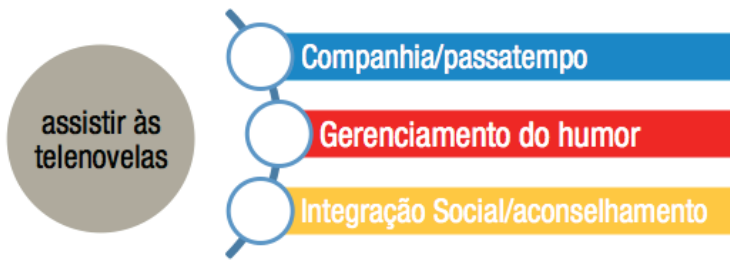

Fonte: FERREIRA, 2011. 
0 primeiro motivo categorizado é identificado pelo destaque da prática repetitiva e frequente da audiência das telenovelas que se institui por hábito, uma disposição apreendida que não tem por fim nada além do que a própria prática de consumo das telenovelas.

0 segundo, relaciona-se a busca da regularização do estado de humor do telespectador, assim, buscar relaxar ou minimizar seu estado de tensão ou vigília, declinar seu estado de excitamento (escape, relaxamento); ou mesmo manter ou elevar seu estado de excitamento/disposição de ânimo (valorização da autoimagem, projeção dos sonhos, fuga do tédio) com as telenovelas é o propósito aqui categorizado. Este motivo para a audiência das telenovelas é denominado de tal foma que o objetivo proposto para exposição às telenovelas é 0 gerenciamento do humor conforme será melhor posto adiante.

A terceira motivação rotulada refere-se a busca de informação e conhecimento, o receptor usa as informações obtidas nas telenovelas para atingir objetivos pessoais em um momento presente/ posterior à exposição. A telenovela nesse sentido é usada para que a audiência venha a se integrar com seus pares no momento da emissão da telenovela, mas também é utilizada, através das suas "agendas propostas", para socialização com outros indivíduos em situações diversas posteriores à transmissão dos seus conteúdos.

Figura 2 - Propriedades da audiência motivada das telenovelas

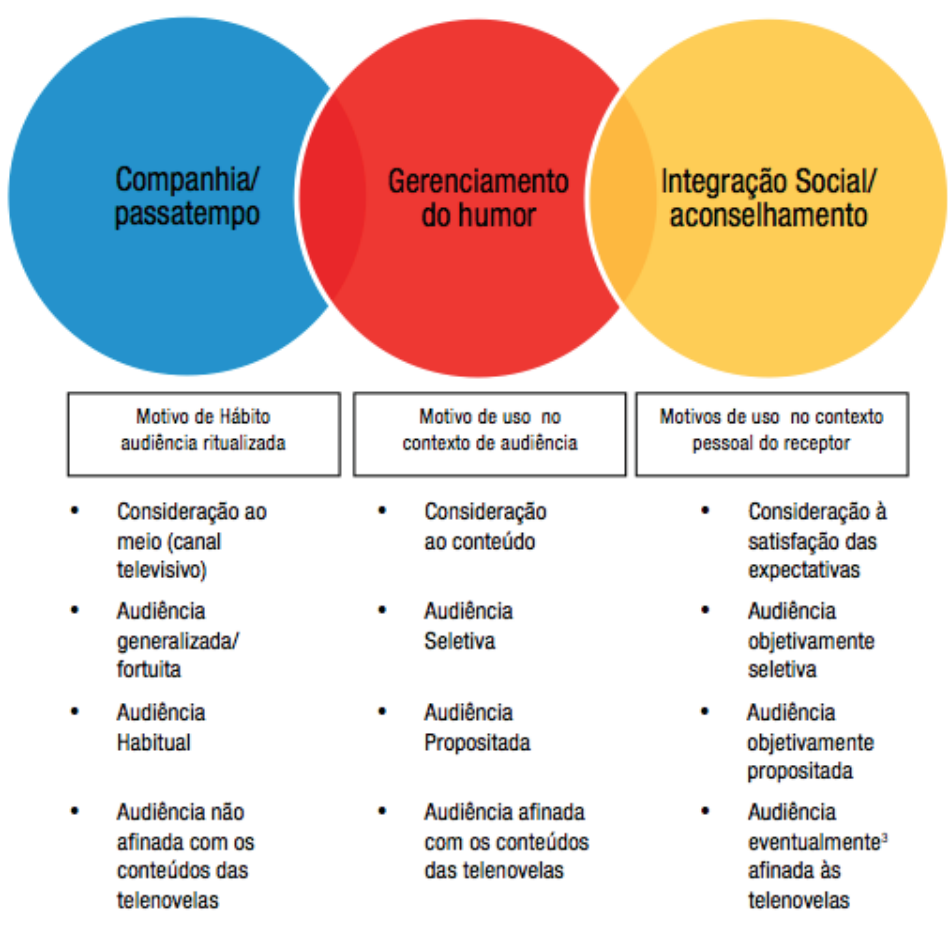

Fonte: FERREIRA, 2011.

A audiência das telenovelas gratificada por aprendizagem/aconselhamento e integração social se encontra "mais sensivelmente" ameaçada por outros conteúdos da programação televisiva porque suas respectivas estratégias de seleção se caracterizam por uma aplicação mais objetivada. 
0 receptor motivado por aprendizagem/

aconselhamento adicionalmente, se apropria dos conteúdos das telenovelas para reflexão das ações e costumes, das características de estilo e de personalidade dos personagens, a fim de que os conhecimentos adquiridos proporcionem a verificação da validade e adequação de sentimentos e comportamentos, reforço das posições pessoais ou mesmo ajustes das suas atitudes e práticas, que 0 ajudará em seu contexto pessoal, a lidar com problemas diversos. Exemplo disso seria a telespectadora recémviúva que utiliza-se das telenovelas para pautar seu comportamento nessa nova situação, ou o adolescente, que verifica as roupas da moda para pautar sua vestimenta e se integrar aos grupos de convívio. 0 comportamento no trabalho, as contradições das relações afetivas, as regras de convívo social são todas variáveis avaliadas e refletidas a partir desses conteúdos.

Igualmente as duas primeiras categorias de motivos descritas, a categoria de busca de Integração social/aconselhamento foi então instituída pela regularidade das características objetivas das motivações que à família se associaram. Nesse contexto, Integração social e Aprendizagem/ aconselhamento foram então agrupadas.

Tal fato se deve particularmente porque enquanto as motivações das duas primeiras categorias são basicamente consumatórias, ou seja, os receptores usam os conteúdos das telenovelas no momento próprio da sua emissão, as motivações do terceiro grupo são caracterizadas pelo uso das telenovelas no âmbito do contexto pessoal do receptor, em um momento que não necessariamente 0 da emissão. Com melhor detalhamento dessas concepções, segue-se a descrição das motivações surgidas do estudo indutivo conduzido já em discussão com a literatura que melhor imterpreta os conceitos surgidos.

\section{$4 \mathrm{~A}$ audiência habitual ou ritualizada das telenovelas (Companhia/passatempo) - discussão dos resultados}

A compreensão da audiência habitual das telenovelas parte da sua associação ao componente Companhia/passatempo, motivo caracterizado com fins pouco pretensiosos pelos receptores. A atividade da audiência se dá de forma pouco envolvida, muito embora, frequente. 0 consumo das telenovelas é uma atividade habitual, repetitiva e rotineira, podendo ser entendida como relativamente "pouco motivada", como também não sujeita a uma argumentação elaborada (BRUBAKER, 2000, p. 327).

A aplicação do receptor à audiência das telenovelas, indiferentemente ao restante da programação televisiva, pode ser conceituada como uma disposição mais ou menos auto acionada, uma tendência da 
audiência engajar-se nesta por uma forma de ação previamente adotada ou adquirida. ${ }^{4}$

Tal característica justifica a denominação Companhia/passatempo. 0 receptor trata a atividade de audiência como secundária, sempre em "companhia" de outra atividade desempenhada como limpar a casa, fazer as refeições, costurar etc., e que ajudaria o receptor com o "passar do tempo". Esse entendimento é originado do próprio automatismo do comportamento da audiência adquirido, no geral, a audiência desse grupo "deixa a emissora transmitir por si" a programação planejada o que a faz consumir por consequência, as telenovelas.

Isso significa saber que a exposição é uma aplicação simples do receptor transformada em uma prática corriqueira (BRUBAKER, 2000) que não tem nenhum fim, que não a sua própria prática. Companhia/passatempo é instituído como habitual porque se caracteriza por uma disposição durável e generalizada do receptor que se aplica à audiência.

Rubin (1984) e Rubin e Perse (1987) já haviam estabelecido duas tipologias do consumo televisivo baseado na observação de receptores mais ou menos ativos em interação com os conteúdos. Uma delas é denominada de "audiência ritualizada", baseada no relacionamento do receptor menos ativo em interação com a televisão.

Esta tipologia habitual relaciona-se a um consumo mais assíduo e mais generalizado da programação, portanto, menos seletivo e com baixos níveis de afinidade com os conteúdos consumidos. Como figurado no estudo da motivação de Companhia/ passatempo, ela é caracterizada como sendo frequente e com alta consideração ao meio televisivo (RUBIN, 1984). Isso significa dizer que a atividade de consumo demonstra ser relevante para 0 receptor, não o conteúdo assistido, sendo inclusive essa audiência, a aproximação menos envolvida com as telenovelas, da mesma forma como observado por Rubin (1984) e Rubin e Perse (1987) em seus respectivos estudos.

\section{$5 \mathrm{~A}$ audiência das telenovelas motivada por Gerenciamento do humor - discussão dos resultados}

Para que se avalie a condição dos usos das telenovelas para 0 gerenciamento do humor do telespectador, é necessário que se volte à literatura que trata das reações provocadas pela interação destes com as telenovelas, isto porque estas estimulam quase sempre a iniciação, neutralização ou a alteração das disposições iniciais ou estados de humor. 
Zillmann (1985, p. 228) no estudo da "exploração experimental das gratificações do entretenimento dos meios" diz que materiais de entretenimento como as telenovelas possibilitam considerável excitação $0^{5}$ através de estímulos como os do suspense, manifestando-se no "[...] domínio simpático obstruso do sistema nervoso automático, entre outras coisas, e produz reações afetivas."

A declaração posta por Zillmann varia segundo as características mais particulares dos estímulos das telenovelas como a apresentação dos elementos do enredo em questão; a variedade de tramas desenvolvidas na história; a dinâmica do desenvolvimento; 0 carisma dos personagens; a intensidade dos estímulos apresentados etc.; e varia, sobretudo também, segundo a disposição inicial do receptor quando se expõe às telenovelas, sendo a lógica ou o esquema apresentado pelo autor único sobre como os receptores gerenciam 0 humor através da iniciação de reações desejáveis (cognitivas e afetivas). Observemos tal lógica.

A proposta de que os receptores desenvolvem "preferências específicas de humor" para com a audiência dos programas televisivos tem tido suporte em pesquisas experimentais cujos receptores se comportam segundo o que parece ser bom para eles sob circunstâncias afetivas específicas (BRYANT; ZILLMANN, 1984 apud ZILLMANN, 1985).
A ideia fundamental do processo seletivo dos conteúdos baseado na regulação do humor é a de que a atratividade dos programas televisivos conecta-se às chances destes ajudarem os receptores a escaparem emocionalmente dos seus respectivos estados de excitação indesejável. Aborrecidos e entediados, por exemplo, acabam mais por se expor aos conteúdos que alteram suas disposições iniciais para um estado mais intenso (das atividades autonômicas destacadamente), com a busca de conteúdos de ação, aventura, animação, comédia, espionagem, terror e suspense ou qualquer coisa que subjetivamente proporcione ao telespectador, fuga do seu estado de humor inicial.

Também, segundo o autor, estressados acabam no geral por escolher programas cujos estímulos são percebidos como neutralizadores dos seus estados de tensão (ainda se acusa em destaque as reações afetivas), isso segundo a lógica de que certos conteúdos podem ocasionar um efeito subjetivamente calmante como um conteúdo romântico, fantasioso, musical, ou qualquer um que subjetivamente proporcione a redução do seu nível de perturbação (ZILLMANN, 1985).

Tais relações podem ser verificadas na descrição dos resultados do estudo Audiência televisiva e excitação fisiológica (ZILLMANN, 1991a), oferecendo mais detalhadamente, a compreensão sobre os processos decisórios da 
programação televisiva amparado pelo desejo de "experimentação de reações afetivas" que levam 0 telespectador a um equilíbrio emocional interno.

Apoiado em estudos endocrinológicos, o autor descreve que uma pessoa que retorna ao lar de um dia de trabalho tenso ou aborrecido acaba por manter um alto nível de excitação inapropriada. Também que a "[...] condição condutiva de tal estado é psicológica, podendo ser identificada como uma preocupação cognitiva continuada sobre os eventos responsáveis pela experiência de estresse" (ZILLMANN, 1991a, p. 106-107). A interrupção de tal processo pode ser conduzida por qualquer forma de estimulação recreativa (que não necessariamente assistir às telenovelas), de distração, ocasionando um efeito benéfico de redução e alívio dos níveis de perturbação do receptor.

Uma das razões para que tal mudança ocorra, conduzida para níveis considerados como apropriados ou próximos do excelente de excitação (níveis menores de estresse, tédio, entre outros), se encontra na capacidade das telenovelas de fornecer estímulos variados que envolvem e absorvem o seu receptor conduzindo-o para outro estado alternativo.

Para além do valor de interesse sobre 0 conteúdo da comunicação, Zillmann aponta que é de especial valor para a intervenção nos processos pontuados acima, o fator da potencialidade de absorção do receptor para o alívio do seu estado particular experimentado. A potencialidade de absorção do receptor relaciona-se por sua vez, diretamente com o denominado "lei do valor inicial", que prediz que é esperado que as reações de excitação dos receptores com uma atividade recreativa sejam variadas, dependendo do estado inicial do receptor no momento da audiência dos conteúdos televisivos.

A exposição aos conteúdos excitantes resultou ser tão calmante quanto à exposição desses receptores aos estímulos tidos como também calmantes, aponta Zillmann para uma das suas conclusões obtidas. Isso se deu porque os receptores cujos estados de excitação eram esperados ser elevados, somente poderiam obter um nível maior de excitação a partir do nível que eles já experimentavam, e desse modo, apenas programas que pudessem estimular a audiência com níveis ainda maiores do que ela já experimentava é que poderia proporcionar os resultados esperados, ou seja, mudanças no estado inicial de disposição/humor.

Tais conclusões em síntese significam saber que os materiais da comunicação social não possuem apenas a capacidade de excitar ou acalmar, têm a capacidade de envolver os seus receptores em diferentes graus de excitação, segundo sempre, 0 estado inicial do receptor no momento da sua exposição, bem como o resultado das suas escolhas operadas sobre a programação.

Do mais é preciso acrescentar que as mudanças de humor ocasionadas com a interação da audiência nas telenovelas têm um íntimo 
relacionamento com os elementos chaves presente nestes conteúdos. Zillmann (1985) fala, por exemplo, que pessoas em estado de muita irritação não podem esperar mudanças de humor favoráveis com a exposição aos materiais que enfatizam ações hostis. Apoiado em pesquisas experimentais, mostra que elas agem como se tivessem tácito conhecimento desses efeitos. Assim, o telespectador irritado tende a privarse do consumo de materiais hostis e a procurar recreação alternativa em outros conteúdos.

Os apontamentos postos por Zillmann em diversos estudos enfim, sustentam parcialmente os achados da pesquisa conduzida sobre os receptores portugueses das telenovelas, em que estes selecionam os conteúdos das telenovelas buscando gratificar-se com a correção dos humores e alcance de um estado de boa disposição ou bem-estar, ou ainda buscando facilitar ou estender estados de bom ânimo quando se expõem às telenovelas.

Tal relação é clara entre os receptores que buscam declaradamente as telenovelas motivados/ gratificados por relaxamento, escape e fuga do tédio, em que prepondera para os dois primeiros, um propósito efetivo de diminuição dos estados de estresse/tensão e agitação/vigília, essencialmente porque com a audiência das telenovelas, estes se desligam dos contextos da origem de tais estados entendidos como desagradáveis. Da mesma forma, o processo inverso também é alcançado com as telenovelas quando estas se mostram adequadas à alteração das disposições iniciais dos receptores, no geral, entediados ou aborrecidos que desejam intensificar seus respectivos níveis de excitação (fuga do tédio).

Mesmo dado à compreensão das conexões entre exposição $X$ gratificações percebidas, as categorias de valorização da autoimagem e projeção dos sonhos são caracterizadas por nuances menos claras das suas respectivas direções. A princípio, os receptores conduzidos ao consumo das telenovelas por estas gratificações procurariam intensificar, manter ou ativar a graus diversos, seus respectivos estados de excitação inicial.

0s receptores das telenovelas quando buscam os materiais que despertam reações afetivas relacionadas a estas condições (orgulho, fascinação pelo destaque da identidade cultural, ou deleite com a projeção das experiências dos sonhos), ${ }^{6}$ obtêm em certas circunstâncias, a alteração dos estados de humor ou ânimo iniciais para outro percebido como prazeroso e desejável.

Em parte, o que motiva os receptores à audiência das telenovelas, são as chances que estas oferecem de "gerenciamento do humor", de neutralização, alteração ou incitação de estados de disposição e ânimo percebidos como apropriados para 0 seu equilíbrio interno. Do mais, a teoria do gerenciamento do humor tem sido utilizada com alguma frequência para esclarecer as gratificações obtidas na televisão, como no estudo de Roe e Minnebo (2007), em que 
associam os relacionamentos problemáticos dos

estudantes belgas-flamengos com um maior consumo

de televisão para "regulação" do humor ou para 0

alcance de reequilíbrio dos estados de humor (ROE;

MINNEBO, 2007).

Formulações como estas são também obtidas nas investigações de Meadowcroft e Zillmann (1987) e Weaver e Laird (1995). No exame das escolhas da programação televisiva das mulheres, foi apontado que as preferências por programas de comédia ou ação/drama estavam associadas à busca de alívio do desconforto e dor causado pelas mudanças fisiologicamente induzidas pelas variações hormonais dos ciclos menstruais das receptoras.

Nessa mesma direção, tantos outros estudos apoiam os conceitos fundamentais das gratificações de gerenciamento do humor com

os programas da televisão como o de Anderson e colaboradores (1996), Bryant e Zillmann (1984), Knobloch e Zillmann (2002) e Westerwick (2007).

\title{
6 A audiência das telenovelas motivada por Integração social e Aconselhamento - discussão dos resultados
}

\author{
A aquisição de um conhecimento se relaciona \\ com o contato subjetivo do receptor com a \\ representação dos significados sociais nas \\ telenovelas em um processo de reação cognitiva \\ aos fluxos de informação. Os estímulos \\ "processados, subjetivamente avaliados \\ e seletivamente armazenados" têm por \\ consequência, a possibilidade de serem levados à \\ prática pelo receptor.
}

Os componentes de atração nas telenovelas que iniciam reações afetivas com os personagens e eventos específicos são percebidos e avaliados pelos receptores. A partir desse processo é determinada alguma tendência destes de se identificarem "com" ou tomarem a perspectiva dos personagens, perceber similaridades, bem como simplesmente gostar de ou se afeiçoar com eventos e elementos presentes nas telenovelas. As afeições se desenvolvem através de vínculos ou associações aos elementos diversos que demonstram possuir atributos avaliados positivamente pelo receptor. Além de empatia, considerações morais suportam o "gosto" "não gosto" disso ou daquilo nas telenovelas, fazendo com que os eventos e personagens nas telenovelas sejam julgados, aprovados ou desaprovados. Com os sentimentos dos receptores estabelecidos pró e contra, vínculos de afinidade, indiferença ou rejeição são estabelecidos com elementos ou eventos específicos desses materiais. A percepção de similaridade (importante para aqueles que se gratificam com a valorização da autoimagem, projeção dos sonhos e aprendizagem/ aconselhamento, por exemplo) é facilitada pelo reconhecimento de características comuns partilhadas, mas também com impressões mais específicas sobre o gênero (feminino/masculino), etnicidade, classe social e idade, impressões sobre 0 caráter das personalidades, tendência do comportamento, experiências ou situações de vida (HOFFNER; CANTOR, 1991). Segundo os autores supracitados, os receptores demonstram apreciar as características de quem eles percebem como similares, inclusive com outras consequências como para aqueles motivados por aprendizagem/aconselhamento, devido à possibilidade de confirmação da validade e propriedade das crenças e comportamentos do receptor, processo esse comumente reconhecido por "identificação", seja tal processo usado para apreciação e regozijo (valorização da autoimagem) ou para fins de instrumentação dos conhecimentos adquiridos. Também, relacionado à tomada da perspectiva dos personagens das telenovelas ou das situações em jogo (importante para aqueles motivados por projeção dos sonhos) o que se tem em processo é a "identificação desejosa", em que os receptores buscam tais perspectivas, segundo o que querem ser, realizar, participar, possuir. Tal processo se desencadearia porque o receptor percebe nos personagens ou situações apresentadas, atributos positivamente avaliados tidos como desejáveis. Elkin (1955) e McGuire, (1974 apud HOFFNER; CANTOR, 1991) em estudo já haviam demonstrado que uma das motivações para a assistência das apresentações ficcionais é a possibilidade de se imaginar nos papéis e situações clamorosas, interessantes ou bem-sucedidas dos personagens. Tal propósito também é ratificado por Radway (2002), em seu estudo Lendo Romance (Reading The Romance), quando aponta que as mulheres são emocionalmente gratificadas pelos romances vicariantes não experimentados no dia a dia. 
Aprender um novo comportamento, tomar decisões, resolver problemas, reforçar posições, estilos e atitudes, integrar-se ao mundo social através dos assuntos das telenovelas são práticas possíveis se os conteúdos das telenovelas se mostrarem adequados a estes propósitos. A exposição seletiva aos conteúdos das telenovelas é então traçada pela combinação do encontro das gratificações esperadas e dos atributos dos conteúdos das telenovelas.

\subsection{Integração social em revista}

Na sua perspectiva sobre o caráter social de materiais como os das telenovelas, Stephenson (1988) identifica as chances de integração social dos receptores quando aponta que as conversas (comunicação interpessoal) principalmente sobre o que é popular (como a própria telenovela), jogam claramente com um fim de sociabilização.

Nesse sentido, as situações mediadas pelo 0 que há de mais popular na sociedade ou em alternativa, situações de perigo comum, seriam as condições que suportariam interesses chaves para integração e sociabilização, "[...] fazendo fácil para todos, de qualquer estado, idade, inteligência, classe, cor, conversar uns com os outros dentro e fora de casa" (STEPHENSON, 1988, p. 89).

As telenovelas dessa forma se mostram efetivas para o propósito de integração social, pois oferecem não somente integração com receptores terceiros no momento da emissão dos seus conteúdos, mas também, em momentos postergados, sendo os assuntos gerados nas telenovelas, 0 elo de troca de impressões e experiências.

Indiferentemente do modo pelo qual a Integração Social efetivamente se estende em prática, tal gratificação encontrada nos conteúdos das telenovelas surge dos dados indutivos guiando e energizando o comportamento da audiência dos receptores. 0 senso de participação e pertença, ou o assunto para a condução de conversas enquanto motivo para exposição aos conteúdos da televisão é tido como relevante em uma série de estudos como o de Rubin $(1981,1985,1988)$, bem como Meyerson (1961) e Chafee, McLeod e Wackman (1973).

Johnstone (1974), por exemplo, na década de 1940 já falava nos usos da audiência para manter contato social, como Lull (1980) já havia também descrito em estudo, “[...] os receptores que adotavam os hábitos televisivos de outras pessoas para fins de interação com estas". 0 uso dos conteúdos da comunicação social para fins de integração social demonstrou, por exemplo, como os pais orientados à família mostravamse receptores pesados da televisão para fins de "melhorar o relacionamento em casa".

Lyle e Hoffman (1972) e Bernstein (1975), respectivamente (apud ATKIN, 2008), também já haviam delineado as predisposições à seleção de programas televisivos que proporcionavam tópicos de conversas entre os adolescentes, bem 
como estes mesmos tópicos oriundos dos conteúdos da comunicação social se constituíam "elos de interação" entre profissionais como cabeleireiros, barbeiros, farmacêuticos e seus respectivos clientes.

\subsection{Aconselhamento em revista}

Procurar aprender, se aconselhar com os conteúdos das telenovelas é outro motivo para a audiência. Isso se dá porque os materiais privilegiados em estudo suportam a representação de certos aspectos relativos ao mundo referente do receptor (STEPHENSON, 1988), e segundo 0 autor, gêneros como os das telenovelas acabam por dizer "um pouco de todos nós" e "tudo dito nelas se aplica em certo grau" (STEPHENSON, 1988, p. 148).

Com as telenovelas, o receptor avalia, reflete as representações dos consensos e não conformidades das ações e costumes, dos significados das normas e regras sociais, dos estilos e características das personalidades. A apreciação de tais situações, em último caso, permite ao receptor, a verificação dos valores que lhe é plausível, da sua afinidade, identificação (ou não) com determinadas personalidades, atitudes, comportamentos.

A aquisição de informação para incremento da credibilidade ou posição pessoal pode ser observada pela influente tradição da sociologia e psicossociologia em estudos da "identificação ou identidade" que se mostram propositados à consideração dessa gratificação em conteúdos como os das telenovelas (BARKER, 1997;

EISENBERG, 2001).

De fato, tal verificação requereria por minha parte uma completa teorização que vai muito além do escopo deste trabalho. Alguns poucos princípios e aspectos conceituais, entretanto, podem aqui ser enunciados dado ao domínio atribuído à discussão posta.

As teorias que conectam a comunicação social e identidade partindo dos pressupostos de que as identidades são em verdade, "retalhos de identidades" (GRIPSRUD, 2002), enunciam que a circunstância de um indivíduo ser aquele que diz ser (ou que é presumido ser segundo terceiros), se constrói através da interação com os outros.

É através da socialização do indivíduo com a família e outras instituições sociais como a igreja, a escola, o trabalho e os meios de comunicação social, que "nos é dito algo sobre quem somos, e 0 que é esperado de nós" (GRIPSRUD, 2002, p. 5). Em conformidade com Stephenson, Gripsrud aponta que a comunicação social, a que 0 gênero das telenovelas pertence, contribui significantemente para a definição do mundo e do indivíduo, porque apresenta sua versão dos retratos e papéis que considera importante, sugerindo "o que" ou "quem" é bom ou ruim, adequado ou inapropriado, chato ou divertido:

Ela apresenta partes e dimensões do mundo que nós não experimentamos diretamente, e podemos nunca experimentar. Como recipientes de tudo 
isso, nós simplesmente temos que formar alguma opinião a respeito de onde estamos localizados, quer dizer, na complexa paisagem apresentada a nós, sobre quem somos, sobre quem gostaríamos de ser - e sobre quem e o que definitivamente não gostaríamos de ser ou de se transformar. Esta complexa percepção de si mesmo é chamada de identidade (GRIPSRUD, 2002, p. 5).

Nesse sentido, a identidade se relaciona com a concepção de ideias, valores e práticas que são semelhantes ou distintas das dos meios (através das telenovelas) apresentadas. ${ }^{7}$ Porque é possível aos indivíduos "escolherem certos elementos da sua personalidade", esses elementos (valores, estilos e comportamentos) apresentados nas telenovelas podem ser incorporados à "colcha da personalidade", dos receptores.

Gripsrud (2002) diz que a formação complexa da identidade é decidida por uma combinação de pertences, papéis e experiências, e que grande parte desses elementos não pode ser escolhida, já outros sim. Enquanto não se escolhe a família onde o indivíduo nasce, o seu ambiente socioeconômico, raça e língua materna, outras escolhas podem ser efetuadas nos termos da extensão das experiências, que quando alargadas, acabam por alterar ou reforçar as características dos indivíduos.

A ideia é oportuna para a discussão porque as escolhas sobre a extensão das experiências e conhecimentos para o incremento da personalidade ou posição pessoal é um dos motivos para que os receptores selecionem e assistam às telenovelas.

Uma das sugestões de Atkin (2008, p. 66, 75) é que "o estímulo do conteúdo é então tido como fonte de aprendizado quando a caracterização, os diálogos ou o cenário são percebidos como oferecendo informação que contribui para a redução de incertezas" e reforço. ${ }^{8}$ Sob esta mesma lógica, Bandura (1969) e Bussey e Perry (1976 apud HOFFNER; CANTOR, 1991) apontam que os receptores podem assumir que os comportamentos dos personagens percebidos como "parecidos", são indicadores importantes de apropriação e efetividade do modo como a audiência se comporta em sociedade. A audiência motivada

Como também de todas as outras instituições sociais.

Tal posição é uma das proposições da literatura da psicologia social dos meios. Com os propósitos do receptor dirigidos ao reforço, 0 autor supracitado conceitualiza três formas básicas de justificativas para a seleção dos conteúdos televisivos. A primeira está baseada na busca dos significados dirigidos a uma condição negativa percebida no contexto do receptor, e cujos conteúdos da comunicação social seriam úteis para a racionalização e reflexão. Também indivíduos com crenças, atitudes ou comportamentos que seriam socialmente desviantes das convenções sociais estabelecidas procurariam seletivamente as telenovelas em busca de legitimação para reforço e diminuição de dissonância cognitiva e afetiva (condizente, por exemplo, aos receptores caracterizados por origens ou experiências profundas de outra cultura que não a portuguesa, que procuram as telenovelas brasileiras para reforço). Esta segunda forma de seletividade motivada por reforço resulta de incerteza sobre a correção de certas crenças, atitudes ou práticas. Um receptor comprometido com uma orientação particular buscaria a validação das suas opiniões e atitudes. Uma terceira condição baseada em reforço ocorre com a expressão de orientações firmemente obtidas, em que os receptores se sentiriam gratificados em observar a representação e celebração de seus valores e a afirmação de seus comportamentos e atitudes padrões (ATKIN, 2008). 
por tais propósitos visaria acessar a validade e adequação dos sentimentos e comportamentos próprios do indivíduo.

Na generalidade, estas formulações se conformam também à teoria da comparação social de Festinger (1954 apud FENIGSTEIN; HEYDUK, 2008) que argumenta que os receptores avaliam suas opiniões e habilidades "comparando-se" com os outros para entendimento de si e da sua situação. Em outras palavras, assistir às telenovelas é a razão para que as experiências dos personagens sugiram abordagens úteis aos receptores para que estes venham a lidar com seus respectivos problemas (MOSCHIS, 1980).

Importante para a exposição que pode até mesmo culminar com a incorporação "de elementos distintos à identidade", ${ }^{9}$ é a mediação do julgamento estético e moral do receptor sobre os elementos com os quais ele tem empatia nas telenovelas. É Zillmann (1991b) quem consolida tal aspecto em seu artigo Empatia: afeição do testemunho das emoções dos outros, quando propõe um modelo da mediação da disposição da empatia aos elementos apresentados.

Em seu modelo, a ação observada pelo receptor (as situações representadas, seus personagens com suas características/estilos/atitudes/ comportamentos) receberia a sua aprovação ou desaprovação. Desaprovação é considerada produzir afeições negativas que por sua vez media afeição discordante ou antipatia aos elementos ou ação observada. Por resultado, tais elementos seriam rejeitados ou criariam "certo distanciamento" da possibilidade de operação pelo receptor.

Já a aprovação das ações observadas produz afeição positiva que media empatia às ações, resultando em aprovação destas (ZILLMANN, 1991b). A empatia ou a identificação com os elementos específicos das telenovelas é então peça chave da atitude do receptor que julga o que lhe parece adequado ou não para reforço ou alteração da sua identidade, de quem ele é, ou quer ou não ser e parecer.

\section{Considerações finais}

A par dos conflitos ou confluências das formulações que determinam a compreensão do comportamento do consumo dos meios, devo mencionar que é crescente 0 desenvolvimento de referenciais teóricos desenvolvidos pelos grupos de estudos cuja ênfase é específica sobre a audiência dos meios da comunicação social. Estes acabam por privilegiar clivagens como: 1) exposição; 2) recepção ou 
interpretação, processos estes fundamentais precedentes sobre qualquer reforço ou mudança de; 3) atitude; 4) comportamento do consumidor da mídia (RUÓTOLO, 1998).

Sob este aspecto, os estudos de exposição a que este trabalho pertence, dividem-se em duas grandes abordagens: os estudos estruturais, que são produzidos pelos institutos de pesquisa de mercado e que privilegiam a mensuração da audiência exposta aos meios e conteúdos em termos de tamanho, características sociodemográficas, frequência da exposição etc., bem como a abordagem de Usos e gratificações, uma tradição influente na pesquisa que tem como foco de estudo, as razões que levam a audiência a selecionar e a se expor aos diferentes meios e conteúdos da comunicação.

Por sua pertinência ao tema abordado neste trabalho, grande parte das motivações encontradas em estudos foi discutida à luz de trabalhos cuja ênfase tinha como foco as razões para 0 consumo dos meios e seus conteúdos. Entretanto, não somente estes foram úteis para maximizar 0 entendimento sobre os motivos para a exposição às telenovelas, também estudos menos conhecidos como os do "Gerenciamento do humor" contribuíram para 0 avanço do seu conhecimento.
Muito embora a descrição dos motivos para a audiência das telenovelas seja apenas uma pequena parte dos resultados do estudo levado a cabo, ${ }^{10}$ é importante reconhecer que 0 conhecimento sobre os processos de decisão da audiência em assistir este ou aquele conteúdo, os usos, os prazeres, são de especial importância porque de fato, esta atividade pessoal não é única ou exclusiva para o receptor.

Na prática, milhares ou milhões de telespectadores se empenham de forma não coordenada nos mesmos processos de decisão, nas mesmas atividades de audiência de conteúdos de alta visibilidade como as telenovelas, e assim, participam também das mesmas agendas, das mesmas expectativas, das mesmas experiências. Esse largo e simultâneo consumo dos materiais dos meios de comunicação social tem diversas consequências relevantes, tanto em âmbito social quanto em âmbito cultural.

Mudanças ou reforço de opiniões e atitudes, práticas e ações sociais que seguem os padrões estabelecidos são, por exemplo, consequências que apenas podem ocorrer na medida em que houver a partida, a decisão seletiva de exposição do receptor aos conteúdos dos meios da comunicação social. Esse processo de decisão é então fundamentalmente importante porque

Ligado à estrutura das motivações, foram identificadas as condições contextuais que pareceram ser proeminentes no surgimento destas; os modos de interação com as telenovelas a partir das motivações identificadas, ou seja, os padrões de estratégias de interação antes durante e depois com as telenovelas; os contextos intervenientes e estruturais à audiência; bem como a relação entre as expectativas junto às telenovelas e os padrões de intensidade de consumo estabelecidos. 
encadeia toda e qualquer possível consequência operada pela atividade de consumo dos conteúdos dos meios como as telenovelas.

\section{Referências}

ATKIN, C. Informational utility and selective exposure to entertainment media. In: ZILLMANN, D.; BRYANT, J. (Ed.). Selective Exposure to Communication. New York: Routledge, 2008. p. 63-92.

ANDERSON, D. et al. Stressful Life Events and Television Viewing. Communication Research, London, v. 23 n. 3, p. 243-260, 1996.

BARKER, C. Global Television: An Introduction. Oxford, UK: Blackwell Publishers 1997.

BRYANT, J.; ROCKWELL, S. Evolving cognitive models in mass communication reception Processes. In: BRYANT, J.; ZILLMANN D. Responding to the screen: reception and reaction processes. New Jersey: Lawrence Publishers, 1991. p. 217-228.

BRUBAKER, R. Social Theory as Habitus. In: ROBBINS, D. (Ed.). Pierre Bourdieu 2. [S.l.]: Sage Publications, 2000. (Sage Masters in Modern Social Thought Series, v. II).

CHAFEE, S; McLEOD, J; WACKMAN, D. B. Family Communication Patterns and Adolescent Media Use. American Behavioral Scientist, Thousand 0aks, v. 14, p. 323-340, 1973.

CUNHA, I. F.; BURNAY C. Ficção televisiva em Portugal: 2000-2005. 2006. Disponível em: < http://bocc.ubi.pt/pag/ ferin-isabel-burnay-catarina-ficcao-televisiva-portugal. pdf> . Acesso em: set.2011.

GRIPSRUD, J. Understanding Media Culture.

London: Arnold Editors, 2002.

EISENBERG, E. Building a Mystery: Toward a new Theory of Communication and Identity. Journal of Communication, v. 51, n. 4. Sept. 2001.
Disponível em: < http:/www3.interscience.wiley.com/ journal/118994144> . Acesso em: maio 2011.

FERREIRA, R. M. C. A experiência da audiência das telenovelas em Portugal. Tese (Doutorado em Ciências da Comunicação) - Universidade Nova de Lisboa, Lisboa, $2011,255 p$.

FENIGSTEIN, A.; HEYDUK, R. Thought and action as determinants to Media exposure. In: ZILLMANN, D.; BRYANT, J. (Ed.). Selective Exposure to

Communication. New York: Routledge, 2008. p. 113-140.

GLASER, B. G. Doing Grounded Theory: Issues and Discussions. Mill Valey: Sociology Press, 1998.

HOFFNER, C.; CANTOR, J. Perceiving and responding to Mass media Characters In: BRYANT, J.; ZILLMANN D. Responding to the screen: reception and reaction processes. New Jersey: Lawrence Publishers, 1991. p. 63-102.

JOHNSTONE, J. Social Integration and mass media use among adolescents: a case study. In: BLUMLER, J. G.; KATZ, E. (Ed.). The use of Mass communications: Current perspective on gratification research. London: Sage, 1974. v. 3, p. 137-164.

KNOBLOCH, S.; ZILLMANN, D. Mood Management Via the Digital Jukebox. Journal of Communication, v. 52, n. 2, p. 351-366, 2002.

LIN, C. A. Modeling the gratification-seeking process of television viewing. Human communication research, Beverly Hills, v. 20, n. 2, p. 224-244, Dec. 1993.

LIN, C. A. Online service adoption likelihood. Journal of Advertising Research, [New York], v. 39, n. 2, p. 79-89, 1999.

LULL, J. Family Communication Patterns and the Social Uses of Television. Communication Research, London, v.7, n. 3, p. 319-334, 1980.

MEADOWCROFT, J. M.; Zillmann, Dolf. Women's Comedy preferences During the Menstrual Cycle. Communication Research, London, v. 14, p. 204-218, 1987.

MEYERSON, R. A Critical Examination of Commercial 
Entertainment. In: KLEEMEIER, R. (Ed.). Aging and Leisure. New York: Oxford university Press, 1961. p. 275-292.

MOSCHIS, G. P. Consumer Information Use: Individual versus social predictors. Communication Research, London, v. 7, n. 2, p. 139-160, Apr. 1980.

RADWAY, J. Reading The Romance. In: MARRIS, Paul; THORNHAM, Sue (Ed.). Media Studies: a reader. Edinburgh: in Press: 2002. p. 492-502.

READING, P. Habit. In: RAMACHANDRAN, V. S.

Encyclopedia of Human Behavior. San Diego, CA: Publisher Academic Press. 1994, v. 2, p. 477. Disponível em: http://www.questia.corn/reader/printPaginator/8. Acesso em: ago. 2010.

ROE, K.; MINNEBO, J. Antecedents of Adolescents' Motives for Television Use. Journal of Broadcasting \& Electronic Media, v. 51, p. 305-315, 2007.

RUBIN, A. M. Ritualized and Instrumental Television Viewing. Journal of Communication, v. 34, n. 3, p. 67-77, 1984.

RUBIN, A. M. A multivariate Analysis of 60 Minutes Viewing Motivations. Journalism Quarterly, v. 58, p. 529-534, 1981a.

RUBIN, A. M. An Examination of Television Viewing Motivations. Communication Research, London, v. 8, n. 2 , p. 141-165, 1981 b.

RUBIN, A. M. Uses of daytime television soap operas by college students. Journal of Broadcasting and Electronic Media. v. 29, n. 3, p. 241-258, 1985.

RUBIN, A. Media Gratifications through the Life Cycle. In: ROSEGREN, Erik, WENNER, L.; PALMGREEN, P. (Ed.). Media Gratifications Research. Beverly Hills: Sage publications, 1985. p. 195-207.

RUBIN, A.; PERSE, E. Audience Activity and Television News Gratifications. Communication Research, London, v. 14, n. 1, p. 58-84, Feb. 1987.
RUBIN, R. B.; PERSE, E. M.; BARBATO, C. A.

Conceptualization and Measurement of Interpersonal Communication Motives. Human Communication Research, v. 14, p. 602-628, 1988.

RUBIN, A. M. Media uses and effects: a uses-andgratifications perspective. In: BRYANT, J.; ZILLMANN, D. Media effects: Advances in theory and research. Washington. DC: Kent State University, 1998.

RUÓTOLO, A. C. F. Audiência e recepção: perspectivas. Comunicação e Sociedade, São Bernardo do Campo, n. 30 , p. 159-170, 1998.

WEAVER, J.; LAIRD, E. Mood Management During the Menstrual Cycle through Selective Exposure to Television. Journalism and Mass Communication Quarterly. v. 72, n. 1, p. 139-146, 1995.

STEPHENSON, W. The play theory of mass communication. New Brunswick, NJ: Transaction Books, 1988.

WESTERWICK, S. K. Gender Differences in Selective Media Use for Mood Management and Mood Adjustment. Journal of Broadcasting and Electronic Media, v. 51, n. 1, p. 73-92, 2007.

ZILLMANN, D. The Logic of Suspense and Mistery. In: BRYANT, J.; ZILLMANN, D. Responding to the Screen: reception and reaction processes. New Jersey: Lawrence Publishers, 1991. p. 281-304.

ZILLMANN, D. Television Viewing and Physiological Arousal. In: BRYANT, J.; ZILLMANN D. Responding to the Screen: reception and reaction processes. New Jersey: Lawrence Publishers, 1991a. p. 103-134.

ZILLMANN, D. Empathy: Affect from Bearing Witness to the Emotions of The Others. In: BRYANT, J.; ZILLMANN D. Responding to the Screen: reception and reaction processes. New Jersey: Lawrence Publishers, 1991b. p. 135-167.

ZILLMANN, D. The Experimental Exploration of Gratifications from Media Entertainment. In: 
ROSEGREN, E.; WENNER, L.; PALMGREEN, P. (Ed.).

Media Gratifications Research. Beverly Hills: Sage

Publications, 1985. p. 225-239.

ZILLMANN, D.; BRYANT, J. Selective Exposure

Phenomena. In: ZILLMANN, D.; BRYANT, J. (Ed.).

Selective Exposure to Communication. New York:

Routledge, 2008. p. 01-10. 


\section{Consumption, Uses and Gratifications of the soap operas' audience}

\section{Abstract}

This article focuses on the partial results of the doctoral thesis defended by the author regarding the audience of soap operas, especially with regard to the reasons for which viewers seek to expose themselves to such content. The Grounded Theory approach was employed to derive a "Soap Operas Spectatorship Model" firmly rooted in the perspectives of 49 soap operas viewers. The resulting model reveals three groups of motives for viewing soap operas: a) Company; b) mood management; c) Social integration / Counseling. Within the model, each motivation group is associated with a particular strategy and level of exposure to soap operas, among others, but here, I highlight the description of each motivational category placed in dialogue with the literature that best interpreted the data arising from applied inductive research.

\section{Keywords}

Soap 0peras. Uses and Gratifications. Audience. Consumption. Grounded Theory.

\section{Consumo, usos y gratificaciones de la audiencia de las telenovelas}

\section{Resumen}

Este artículo se centra en los resultados parciales de la tesis doctoral defendida por la autora acerca de los usos de las telenovelas, especialmente con respecto a las razones que los espectadores tienen para seleccionar dichos contenidos. El enfoque de la "Teoria fundamentada en datos" fué utilizada para proporcionar un "MODELO DE LAAUDIENCIA DE LAS TELENOVELAS" firmemente arraigado en la perspectiva de 49 receptores encuestados. El modelo resultante revela tres categorías de razones para la asistencia: a) Pasatiempo; b) gestión del estado de humor; c) integración social/Consejería. Cada grupo de razones en el modelo se asocia con una estrategia particular, una intensidad de exposición a las telenovelas, patrones de interacción entre otros, pero aquí, voy a destacar la descripción de cada categoría de motivación puesto en causa com la literatura que mejor interpreta los datos derivados de la investigación inductiva aplicada.

\section{Palabras-Clave}

Telenovelas. Usos y gratificaciones. Audiencia. Consumo. Teoria fundamentada en datos. 


\section{Expediente}

A revista E-Compós é a publicação científica em formato eletrônico da Associação Nacional dos Programas de Pós-Graduação em Comunicação (Compós). Lançada em 2004, tem como principal finalidade difundir a produção acadêmica de pesquisadores da área de Comunicação, inseridos em instituições do Brasil e do exterior.

\section{E-COMPÓS I www.e-compos.org.br I E-ISSN 1808-2599}

Revista da Associação Nacional dos Programas

de Pós-Graduação em Comunicacão.

Brasília, v.17, n.1, jan./abri. 2014.

A identificação das edições, a partir de 2008

passa a ser volume anual com três números.

\section{CONSELHO EDITORIAL}

Afonso Albuquerque, Universidade Federal Fluminense, Brasil Alberto Carlos Augusto Klein, Universidade Estadual de Londrina, Brasil Alex Fernando Teixeira Primo, Universidade Federal do Rio Grande do Sul, Brasil Ana Carolina Damboriarena Escosteguy, Pontifícia Universidade Católica do Rio Grande do Sul, Brasi

Ana Gruszynski, Universidade Federal do Rio Grande do Sul, Brasil Ana Silvia Lopes Davi Médola, Universidade Estadual Paulista, Brasil André Luiz Martins Lemos, Universidade Federal da Bahia, Brasi Ângela Freire Prysthon, Universidade Federal de Pernambuco, Brasil Antônio Fausto Neto, Universidade do Vale do Rio dos Sinos, Brasil Antonio Carlos Hohlfeldt, Pontifícia Universidade Católica do Rio Grande do Sul, Brasil Antonio Roberto Chiachiri Filho, Faculdade Cásper Líbero, Brasi Arlindo Ribeiro Machado, Universidade de São Paulo, Brasil Arthur Autran Franco de Sá Neto, Universidade Federal de São Carlos, Brasil Benjamim Picado, Universidade Federal Fluminense, Brasil César Geraldo Guimarães, Universidade Federal de Minas Gerais, Brasil Cristiane Freitas Gutfreind, Pontifícia Universidade Católica do Rio Grande do Sul, Brasil Denilson Lopes, Universidade Federal do Rio de Janeiro, Brasil Denize Correa Araujo, Universidade Tuiuti do Paraná, Brasi Edilson Cazeloto, Universidade Paulista , Brasil

Eduardo Vicente, Universidade de São Paulo, Brasil Eneus Trindade, Universidade de São Paulo, Brasil Erick Felinto de Oliveira, Universidade do Estado do Rio de Janeiro, Brasi Florence Dravet, Universidade Católica de Brasília, Brasil Gelson Santana, Universidade Anhembi/Morumbi, Brasi Gilson Vieira Monteiro, Universidade Federal do Amazonas, Brasil Gislene da Silva, Universidade Federal de Santa Catarina, Brasil Guillermo Orozco Gómez, Universidad de Guadalajara Gustavo Daudt Fischer, Universidade do Vale do Rio dos Sinos, Brasil Hector Ospina, Universidad de Manizales, Colômbia Herom Vargas, Universidade Municipal de São Caetano do Sul, Brasil Ieda Tucherman, Universidade Federal do Rio de Janeiro, Brasil Inês Vitorino, Universidade Federal do Ceará, Brasil Janice Caiafa, Universidade Federal do Rio de Janeiro, Brasil Jay David Bolter, Georgia Institute of Technology Jeder Silveira Janotti Junior, Universidade Federal de Pernambuco, Brasi João Freire Filho, Universidade Federal do Rio de Janeiro, Brasil John DH Downing, University of Texas at Austin, Estados Unidos
José Afonso da Silva Junior, Universidade Federal de Pernambuco, Brasil José Carlos Rodrigues, Pontifícia Universidade Católica do Rio de Janeiro, Brasil José Luiz Aidar Prado, Pontifícia Universidade Católica de São Paulo, Brasil José Luiz Warren Jardim Gomes Braga, Universidade do Vale do Rio dos Sinos, Brasil Juremir Machado da Silva, Pontifícia Universidade Católica do Rio Grande do Sul, Brasil Laan Mendes Barros, Universidade Metodista de São Paulo, Brasil Lance Strate, Fordham University, USA, Estados Unidos Lorraine Leu, University of Bristol, Grã-Bretanha Lucia Leão, Pontifícia Universidade Católica de São Paulo, Brasil Luciana Panke, Universidade Federal do Paraná, Brasil Luiz Claudio Martino, Universidade de Brasília, Brasil Malena Segura Contrera, Universidade Paulista, Brasil Márcio de Vasconcellos Serelle, Pontifícia Universidade Católica de Minas Gerais, Brasil Maria Aparecida Baccega, Universidade de São Paulo e Escola Superior de Propaganda e Marketing, Brasil Maria das Graças Pinto Coelho, Universidade Federal do Rio Grande do Norte, Brasil Maria Immacolata Vassallo de Lopes, Universidade de São Paulo, Brasil Maria Luiza Martins de Mendonça, Universidade Federal de Goiás, Brasil Mauro de Souza Ventura, Universidade Estadual Paulista, Brasil Mauro Pereira Porto, Tulane University, Estados Unidos Nilda Aparecida Jacks, Universidade Federal do Rio Grande do Sul, Brasil Paulo Roberto Gibaldi Vaz, Universidade Federal do Rio de Janeiro, Brasil Potiguara Mendes Silveira Jr, Universidade Federal de Juiz de Fora, Brasil Renato Cordeiro Gomes, Pontifícia Universidade Católica do Rio de Janeiro, Brasil Robert K Logan, University of Toronto, Canadá

Ronaldo George Helal, Universidade do Estado do Rio de Janeiro, Brasil Rosana de Lima Soares, Universidade de São Paulo, Brasil Rose Melo Rocha, Escola Superior de Propaganda e Marketing, Brasil Rossana Reguillo, Instituto de Estudos Superiores do Ocidente, Mexico Rousiley Celi Moreira Maia, Universidade Federal de Minas Gerais, Brasi Sebastião Carlos de Morais Squirra, Universidade Metodista de São Paulo, Brasil Sebastião Guilherme Albano da Costa, Universidade Federal do Rio Grande do Norte, Brasil

Simone Maria Andrade Pereira de Sá, Universidade Federal Fluminense, Brasil Tiago Quiroga Fausto Neto, Universidade de Brasilia, Brasil Suzete Venturelli, Universidade de Brasília, Brasil Valerio Fuenzalida Fernández, Puc-Chile, Chile Veneza Mayora Ronsini, Universidade Federal de Santa Maria, Brasil Vera Regina Veiga França, Universidade Federal de Minas Gerais, Brasil

\section{COMISSÃO EDITORIAL}

Cristiane Freitas Gutfreind I Pontifícia Universidade Católica do Rio Grande do Sul, Brasil Irene Machado I Universidade de São Paulo, Brasil

Jorge Cardoso Filho I Universidade Federal do Reconcavo da Bahia, Brasil / Universidade Federal da Bahia, Brasil

CONSULTORES AD HOC

Adriana Amaral, Universidade do Vale do Rio dos Sinos, Brasil

Alexandre Rocha da Silva, Universidade Federal do Rio Grande do Sul, Brasi Arthur Ituassu, Pontifícia Universidade Católica do Rio de Janeiro, Brasil Bruno Souza Leal, Universidade Federal de Minas Gerais, Brasil Elizabeth Bastos Duarte, Universidade Federal de Santa Maria, Brasil Francisco Paulo Jamil Marques, Universidade Federal do Ceará, Brasi Maurício Lissovsky, Universidade Federal do Rio de Janeiro, Brasil Suzana Kilpp, Universidade do Vale do Rio dos Sinos, Brasil Vander Casaqui, Escola Superior de Propaganda e Marketing, Brasil

EDIÇÃO DE TEXTO E RESUMOS I Susane Barros SECRETÁRIA EXECUTIVA I Helena Stigger EDITORAÇÃo ELETRÔNICA I Roka Estúdio
COMPÓS I www.compos.org.br

Associação Nacional dos Programas de Pós-Graduação em Comunicação

Presidente

Eduardo Morettin

Universidade de São Paulo, Brasil

eduardomorettin@usp.br

Vice-presidente

Inês Vitorino

Universidade Federal do Ceará, Brasil

ines@ufc.br

Secretária-Geral

Gislene da Silva

Universidade Federal de Santa Catarina, Brasil

gislenedasilva@gmail.com 